\title{
Actualization of Islam Nusantara Values at Madrasah Qudsiyyah Kudus
}

\author{
Ihsan \\ IAIN Kudus, Kudus, Indonesia \\ ihsan@iainkudus.ac.id \\ Achmad Zuhri \\ IAIN Kudus, Kudus, Indonesia \\ achmadzuhri@iainkudus.ac.id \\ Azwar Annas \\ IAIN Kudus, Kudus, Indonesia \\ azwarannas@iainkudus.ac.id \\ Hanik Hidayati \\ Universitas Muria Kudus, Indonesia \\ Hanik.hidayati@umk.ac.id
}

\begin{abstract}
This study aims to elucidate the portrait of an educational institution that actualizes Islam Nusantara values in the process of transferring knowledge to the students. This study applied a qualitative approach. Data was collected through interviews and documentation at one madrasah in Kudus City, Central Java, namely Madrasah Qudsiyyah, which is very close to local traditions and culture. This study's results revealed that the forms of Islam Nusantara values actualization in this institution were generally depicted in the uniform as madrasah identity, teaching materials/references using Javanese, learning methods, activity essences both in routine activities and specific events, and the teachers' productivity with their scientific specifications; thus, they give nuances that are typical of the archipelago in this madrasah.
\end{abstract}

Keywords: Madrasah Qudsiyyah; Islam Nusantara; Actualization 


\begin{abstract}
Abstrak
Kajian ini bertujuan untuk mendeskripsikan potret sebuah lembaga pendidikan yang mengaktualisasikan nilai islam nusantara dalam proses transfer ilmu kepada para siswanya. Pendekatan kajian ini adalah kualitiatif dengan metode pengumpulan data wawancara, observasi dan dokumentasi pada salah satu madrasah di kaki menara Kudus yakni Madrasaah Qudsiyyah yang sangat erat dengan tradisi dan budaya setempat. Hasil kajian ini menunjukkan bahwa bentuk aktualisasi nilai Islan Nusantara di lembaga ini secara garis besar tergambar pada seragam sebagai identitas madrasah, bahan ajar/refrensi yang digunakan menggunakan Bahasa Jawa, metode pembelajran, senyawa kegiatan baik kegiatan rutin maupun even tertentu, dan produktivitas guru dengan spesifikasi keilmuan yang dimilikinya sehingga memberikan warna dan nuansa yang khas Nusantara di madrasah ini.
\end{abstract}

Kata kunci: Madrasah Qudsiyyah; Islam Nusantara; Aktualisasi

\title{
A. Introduction
}

Islam Nusantara is a concept that explicates the Indonesian Muslims' mindset and behavior as a reflection of how they comprehend, teach, and implement Islamic teachings that are distinctive to the archipelago. Islam Nusantara is not a new school of thought (mazhab) in Islamic history. Islam Nusantara is related to the methods (manhaj) and procedures (kayfiyah) employed by Muslim scholars in Indonesia to spread Islamic teachings to be easily understood and implemented by the Indonesian people (Al-Zastrouw 2017, 1).

Substantively, Islam Nusantara is an Islamic understanding and its implementation, which takes place in Indonesian region, as a result of the synthesis between revelation and local culture. Therefore, it contains nuances of local wisdom with the Islamic components, "the orthodoxy of Islam Nusantara is Asy'ariah kalam (theology), Syafi'i fiqh, and al-Ghazali Sufism". Besides these three components, three more components can be added to strengthen the Islam Nusantara concept are political, educational, and cultural components. For that reason, the object of Islam Nusantara study must at least encompass six components: kalam (theology), fiqh, Sufism, politics, education, and culture (tradition) (Qomar, 2015).

On the other hand, educational institutions are the most accessible media to instill the students' Islamic style. By utilizing local culture as a medium, the educational concept about Islam is one of the approaches launched by religious leaders to eliminate the stigma that everything coming from Arabia makes it true (Abdullah 2016, 64). For this reason, Islam Nusantara is a solution to reinforce Indonesian because respecting diversity is a fact of the 
Unitary State of the Republic of Indonesia. Making Islam Nusantara as a discourse and spirit instilled in students is a necessity to strengthen Indonesians. By doing it, Islam's mission as rahmatan lil alamin is embodied in Islam Nusantara model.

In this case, one of the educational institutions in Menara Kudus, a historic building left by Walisongo Sunan Kudus, closely related to the history of Islamic education in Indonesia. Through his da'wah, Walisongo succeeded in combining methods from the spiritual aspect and accommodating the local community traditions by establishing a pesantren (Islamic boarding school), a place for da'wah and teaching and learning. It is Madrasah Qudsiyyah Kudus, which is more than a century old and is closely associated with its ancestors' traditions and culture. It was founded by a charismatic kyai (cleric) and driving figure of Nahdlotul Ulama, KHR. Asnawi. This madrasah, which is geographically located around Menara Kudus, is included in the category of the oldest madrasah in Kudus City. Established in 1919, until now, it has continued to grow rapidly, in which there are several levels of education, ranging from MI (Islamic elementary school), MTs (Islamic junior high school), and MA (Islamic senior high school). It is also equipped with a boarding school integrated with the madrasah. Beside that, Madrasah Qudsiyyah is a religion-based educational institution which applies the Religious Affairs Ministry curriculum with the local curriculum. The combination of general and Salafi subjects makes this madrasah superior in the field of religion without compromising general knowledge. The dominance of pesantren-based subjects in this institution also makes all students from all levels referred to as santri.

As Sunan Kudus teachings were very tolerant of the culture formed and rooted in Kudus community, the masyayikh in Madrasah Qudsiyyah as the movers and successors of their ancestors continue to innovate in the process of transferring knowledge by incorporating Islamic values and teachings into the Javanese society's traditions and culture. It aims to contextualize a modern civilization that continues to surround and not get caught up in the thickening of the normative and romantic past, thus dragging it into unanticipated changes.

Therefore, this paper attempts to describe the portrait of Madrasah Qudsiyyah, seeks to actualize Islam Nusantara values within the educational framework so that students know and understand their ancestors' history and are not "lali weton" or not against their traditions. The legacy of Indonesian masyayikh ulama, thus, remains the cultural and intellectual heritage and wealth of the archipelago.

In accordance with the objectives and results to be achieved in this study, the method chosen was qualitative with a phenomenological approach (Muhadjir 2002). This approach was employed to interpret every meaning in every phenomenon, symbol, and activity of 
Madrasah Qudsiyyah santri and base all its analysis on data and facts encountered in the field so that it was not pre-determined ideas.

Thus, the research data were extracted in two stages: data collection from human sources and data collection from non-human sources (Guba, E. G. \& Lincoln 1985). For the first type of data source, the technique used included observation of teaching and learning activities. Meanwhile, for the second type of data source, a documentation technique was utilized. In addition, checking the data validity (trustworthiness) was carried out through 1) credibility, 2) transferability, 3) dependability, and 4) confirmability (Guba, E. G. \& Lincoln 1985).

\section{B. Discussion}

\section{Islam Nusantara: Religious and Cultural Relations}

Islam Nusantara is Islam that was born and grew covered by Indonesian culture and traditions; Islam that is tolerant, friendly, and peaceful. Abdurrahman Wahid described Islam Nusantara in his idea of "Indigenization of Islam" as normative teaching that comes from God, which is then actualized in a culture that originates from humans without losing its identity (Rahmat 2007, xx). Islam Nusantara stands between contradictory notions, namely fundamentalism, and liberalism.

Islam Nusantara consists of two words: Islam and Nusantara. Islam means obedience, submission, and peace. This religion has five central teachings, as explained by the Prophet Muhammad SAW, namely testifying that there is no God but Allah and Prophet Muhammad is the messenger of Allah SWT, establishing prayer, paying zakat, fasting, and performing Hajj for those who can afford it (Luthfi 2016, 3). In addition, Islam has two reference guidelines: the Quran and Hadith. Both contain teachings that guide humankind and the universe in a better and orderly direction.

Moreover, the arrival of Islam Nusantara was not to change the doctrine of Islam but only to find a method for putting Islam in the context of the diverse cultures of the local community. Islam Nusantara also does not combine Javanese and Islamic religions or syncretism efforts but integrates cultural awareness in carrying out da'wah strategies, as has been exemplified by Walisongo. In line with the Nusantara culture development, it can be seen how Islamic cultural values have fused with local cultural values in several Indonesian regions in the form of traditions, cultural arts and physical relics (Azisi 2020, 126). 
Gus Mus (KH. Mustofa Bisri) also gave an explanation of what Islam Nusantara is. According to him, the word 'Nusantara' will be misunderstanding if understood it in the structure of na'at-man'ut, or the characterization of being "Islam-made Nusantara". However, it is correct if placed in the structure of idhāfah (designation of place), which means "Islam in Nusantara" (Azisi 2020, 125).

Regarding Gus Mus explanation of Islam Nusantara above, it is not wrong when it was intended in the context of alleviating all fears of a group, which misunderstood in understanding the true meaning of Islam Nusantara. However, it should be noted that the designation of an area can also be interpreted to reveal everything, all the elements contained in an area. Therefore, whether like it or not, the Indonesian people must continue to maintain and embrace the region's features, characteristics, and character, which is called Nusantara. Therefore, Nusantara has its characteristics in applying Islamic values, which are fused to the Indonesian people culture (Azisi 2020, 125).

In line with what was conveyed by Zastrouw el-Ngatawi, historically-sociologically, there are two things causing the emergence of the Islam Nusantara construction. First, the Quran and hadith only contain the universal Islamic teachings' basic principles and values. Thus, implementation instructions and technical guidelines are needed in accordance with social realities and society's context to be operationally applied. In this case, it can be analogous to the existence of the Constitution. The Constitution only contains fundamental principles and outlines of the main idea. In order for the Constitution to be implemented, derivative regulations are required, such as Laws, Government Regulations, Ministerial Regulations, Regional Regulations, and so on. In order to understand and implement the Constitution made by humans, a multi-level instrument is needed, let alone understand and apply Islamic teachings which are universal and made by God; then, of course, more complex and complicated explanatory devices and operational instructions are necessary (Al-Zastrouw $2017,4)$.

Second, the social and cultural reality of Indonesian society is entirely different from Arabic society. Therefore, when the teachings of Islam descended using Arabic, while Indonesian people have various languages, a device is needed to understand the Quran and Hadith that used Arabic. It is where the gap arises in the delivery of religious teachings. To reduce this cultural gap, Indonesian community leaders, in this case, wali and kyai, try to translate the teachings of Islam into a cultural language in accordance with the level of understanding and social conditions of Indonesian (billisani Qaumihim) (Al-Zastrouw 2017, 5). 
Furthermore, the term Nusantara is a description of the area that stretches from Sumatra to Papua Islands. This word derives from Javanese manuscripts around the 12th to 16th centuries as a concept introduced by the Majapahit State at that time. Whereas in the 19th century, in English-language literature, Nusantara referred to the Malay Archipelago. Meanwhile, Ki Hajar Dewantoro used this term in the 20th century to recommend the designation of a territory of the Dutch East Indies (Kroef 1951, 166-171). Nusantara is usually synonymous with Indonesia because most of these islands are in the territory of the Indonesian State. This term, constitutionally, was confirmed by the Presidential Decree of the MPR No. IV/MPR/1973 concerning the Outline of State Policy Chapter II Sub E. Before the word Nusantara, the word "insight" was added.

Referring to the above understanding, the term Islam Nusantara is the religious teachings in the Quran and Hadith practiced by the Prophet Muhammad, followed by the natives of the archipelago (Indonesia), or the people who live in it. However, if it is associated with the views of every Muslim or a particular Islamic organization, the concept of Islam Nusantara will be complex, as happened in the most prominent Islamic organization in the world, Nahdlotul Ulama (NU). Officially, the term Islam Nusantara was launched at the 33rd Nahdlotul Ulama Congress in Jombang, with the theme "Strengthening Islam Nusantara for Indonesian Civilization and the World". However, many figures have different concepts. The differences in views regarding the term Islam Nusantara among intellectuals are on the label of "Islam" followed by the word "Nusantara". The word "Nusantara" can give meaning not only normatively but also variedly in Islam. When Islam and Nusantara become a phrase "Islam Nusantara", the meaning is diverse based on the angle of view or scientific approach used (Luthfi 2016, 4).

First, a philosophical approach defines Islam Nusantara as a non-positivistic term, as a value system, substantive Islam, and a means of analysis. Isom Yusqi (nu.or.id) positions Islam Nusantara as an approach to studying Islam, creating various disciplines, such as Nusantara fiqh, Nusantara muamalah, Nusantara siyasah, Nusantara qanun, Nusantara Islamic banking, Nusantara Islamic economics, and various other branches of Islamic science which are based on Nusantara socio-episteme.

The second is cultural approach. From this approach, three terms emerged: Islam Nusantara as marine Islam, everyday Islam, and model. Islam Nusantara as "marine Islam" is a form of Islamic practice that comes from the maritime community lifestyle, usually associated with new arrivals from various islands. Radhar Panca Dahana showed the Islam Nusantara characteristics as beliefs and faiths that are different, open, egalitarian, and do not feel superior 
to one another. This character is taken from the straight and equal Indonesian sea horizon (Luthfi 2016, 4). Besides, Faisol Ramdhoni explained that Islam Nusantara with " everyday Islam" means the implementation of Islamic teachings related to worship procedures, rituals, and other religious traditions, which have been carried out, passed down and instilled by the ancestors in the daily religious practices of the community (Ramdhoni, 2016). Meanwhile, the notion of Islam Nusantara as a "model", described by Imam Bukhari, Dawam Multazam, and Imam Aziz, is used as an example of an ideal Islam that can be applied throughout the world; for example, it can be seen from the Islam practiced by nahdliyyin citizens since the Walisongo era (Luthfi 2016, 4).

Third, a linguistic approach that displays the term Islam fi Indonesia. Luthfi (2016) explained that the term Islam Nusantara was coined by Umar A.H, who defined it by analogizing the phrase fi in Arabic. According to him, Islam Nusantara is not an attempt to localize Islam or create a Islam Nusantara "religion", but an attempt to understand and apply Islam without compromising the place where Islam is believed and embraced Indonesia. Islam Nusantara is the same as Islam practiced in Indonesia in a geographical sense.

Fourth, the historical-anthropological approach gave birth to two terms: Islam of typical Indonesia and Islam of Nusantara Culture. What is meant by Islam Nusantara as typical Indonesian Islam is Islam uniquely Indonesian-style, a combination of Islamic theological values with the values of local traditions, culture, and customs in Indonesia. In this context, the culture of a particular region or country occupies an equal position with Arab culture in absorbing and carrying out Islamic teachings. A tradition of Islam Nusantara shows an Islamic tradition from various regions in Indonesia, which symbolizes the Islamic culture of the area (www.nu.or.id).

This term was coined by Said Aqil Siradj, Chairman of PBNU, Executive Board of Nahdlatul Ulama. According to him, Islam Nusantara is Islam that only Indonesia has, namely the heterogeneous pattern of Islam Nusantara. One area with another area has its characteristics but has the same spirit. The similarity of breath is the essence and wisdom of the long journey of Islam for centuries in Indonesia, which has resulted in a characteristic that prioritizes the esoteric aspects of truth rather than the exoteric shari'a (Luthfi 2016, 5).

Azyumardi Azra also provides a definition of Islam Nusantara as a distinctive Islam derived from the interaction, contextualization, indigenization, and vernacularization of universal Islam with social, cultural, and religious realities in Indonesia. The orthodoxy of Islam Nusantara (Asy'ari kalam, Syafi'i fiqh, and Ghazali Sufism) fosters a moderate and tolerant 
character of wasathiyah. Islam Nusantara, which is rich in Islamic legacy, is the hope of the global Islamic civilization renaissance (Azra 2004).

Meanwhile, according to Zastrouw el-Ngatawi, Islam Nusantara has gone through four phases of development until internalized in Indonesian society because it has three abilities: hamengku (a new culture can be preserved), hangemot (a newly entered culture is given a place), and hangemong (culture can be fostered) so that it can be harmonious in the life of the Indonesian people (Lubis 2018).

In agreement with Zastrouw, Hanum described that Islam Nusantara tries to make religion and culture not defeat each other, but to embody it in a pattern of religious reasoning that no longer takes its authentic religious form and try to bring together the same bridge that has been separating religion and culture; thus, there is no longer a conflict between religion and culture. For instance, the wali in Java tried to introduce Islam through tradition so they needed to study the existing kekawian (classical literature) and various performing arts from various serat or created books (Astuti 2017, 50).

Hence, the understanding of the Islam Nusantara manhaj in Indonesia is that Islam Nusantara is not a new religion, nor is it a new sect. Islam Nusantara is a thought based on the history of Islam that entered Indonesia, not through war but a compromise on culture. Islam Nusantara does not justify the existence of a tradition that is contrary to Islamic law (Asnawi 2017, 254).

In other words, Islam Nusantara is an Islamic identity in terms of the region, which can be equated with Arab Islam, Indian Islam, Turkish Islam, and so on. Islam Nusantara is a model of thought, understanding, and practice of teachings. Islam, through a cultural approach, thus, reflects the Islamic identity with a methodological nuance. Islam Nusantara also exhibits the thinking, understanding, and practice of Islam, which is moderate, inclusive, tolerant, peace-loving, soothing, nurturing, and respecting diversity; thus, the existence of Islam Nusantara is the antithesis of radical actions in the name of Islam (Qomar 2015, 2013-2014).

From the existing definitions, Islam Nusantara has five particular characteristics that distinguish it from Islam in Arabia: contextual with the conditions of the times that are constantly changing, tolerant of differences that exist in Nusantara, respecting existing traditions with acculturation, always be progressive towards the progress of era and giving freedom to the people in making choices in Islamic law. 


\section{Education Portrait of Islam Nusantara at Madrasah Qudsiyah Kudus}

\section{a. Institutional identity (uniform)}

The reflection of the Islam Nusantara values, which was obvious and could be directly seen by the naked eye, is the madrasah uniform worn by teachers and students with typical Indonesian clothes. Batik uniform as one of the typical clothes of Indonesia was worn every Saturday and Sunday. In addition, the typical Kudusan uniform was also scheduled every Thursday by wearing a headband, batik sarong, and white shirt. That way, the students could get to know the Indonesian culture implied in madrasah uniform. In addition, the students could also understand the meaning of Islam Nusantara implied in the uniforms they wore that the Islam Nusantara style is not a robe but a batik sarong. As evidenced, this traditional dress has become a symbol attached to students and santri, as seen in the following documentation.

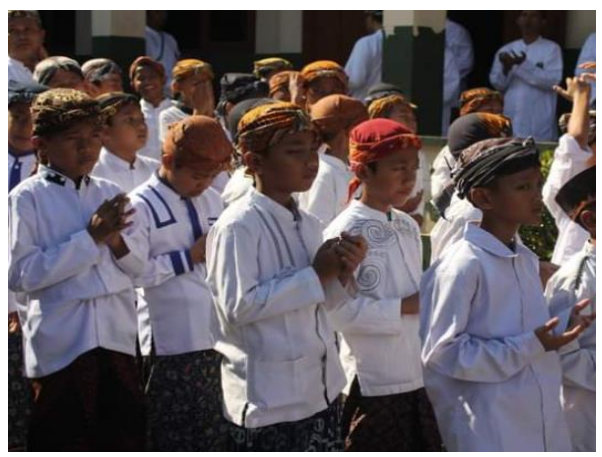

Picture of the Madrasah Qudsiyyah Uniform, with a typical Kudusan headband

\section{b. Teaching Materials/References in Javanese}

Another invaluable heritage of Islam Nusantara is the emergence of many Nusantara scholars and their masterpieces, which until now continue to be a source of knowledge and research for Indonesian and the world intellectuals (Darajat 2015, 84-85). Some works of the founding elders of madrasah, which still exist, were used as teaching materials in the learning process, including Kitab Fashalatan, Tauhid Jawan, Kitab Soal Jawab Mu'takad Seket, the work of KHR Asnawi as the founder. KH. Yahya Arif, one of the Madrasah Qudsiyyah masyayikh, also wrote books used as learning modules, such as nahwu, lughah, mahfudhat, fiqh, ushul fiqh, falak (astronomy), faraidl, and many more. As nadzir of Madrasah Qudsiyyah, KH. M. Sya'rani Ahmadi also published various books from various disciplines as shown in the table below. 
Ihsan, Achmad Zuhri, Azwar Annas, Hanik Hidayati

List of Javanese Books at Madrasah Qudsiyyah Kudus

\begin{tabular}{|c|c|c|c|c|c|}
\hline No & Book & Author & Subjects & Level & $\begin{array}{r}\text { Descri } \\
\text { ption }\end{array}$ \\
\hline 1 & $\begin{array}{l}\text { Al Muntakhabat fi al } \\
\text { Mahfudhat wa Allughat al } \\
\text { Mufrodat }\end{array}$ & KH. Yahya Arif & Mahfudhat & Ibtidaiyyah & Juz 1-4 \\
\hline 2 & Al Qiro'ah Al Tarijiyyah & KH. Yahya Arif & Qiro’ah & Ibtidaiyyah & \\
\hline 3 & Jawahirul Adab & KH. Yahya Arif & $A d a b$ & Ibtidaiyyah & \\
\hline 4 & $\begin{array}{lr}\text { Irsyadul } & \text { Mustarsyid Fi } \\
\text { Tarjamati } & \text { Jauharotut } \\
\text { Tauhid } & \end{array}$ & KH. Yahya Arif & Tauhid & Ibtidaiyyah & Juz 1-2 \\
\hline 5 & $\begin{array}{l}\text { Arrisalah Al Mukhtasharrah } \\
\text { fi al 'Aqa'idil Khamsina }\end{array}$ & KH. Yahya Arif & Tauhid & Ibtidaiyyah & \\
\hline 6 & Tarjamah Risalatut Tauhid & KH. Yahya Arif & Tauhid & Ibtidaiyyah & \\
\hline 7 & Fasholatan Qudsiyyah & KH. Yahya Arif & Fiqih & Ibtidaiyyah & Juz 1-2 \\
\hline 8 & $\begin{array}{l}\text { Tarjamah } \quad \text { Addurusul } \\
\text { Fiqhiyyah }\end{array}$ & KH. Yahya Arif & Fiqih & Ibtidaiyyah & Juz 1-4 \\
\hline 9 & Hadist 41 & KH. Yahya Arif & Hadist & Ibtidaiyyah & \\
\hline 10 & $\begin{array}{l}\text { 'athiyyatul Qudsy Fi } \\
\text { Tarjamati Al 'Arbain } \\
\text { Annawawi }\end{array}$ & KH. Yahya Arif & Hadist & Ibtidaiyyah & \\
\hline 11 & Qawa'idul I'rob & KH. Yahya Arif & I'rob & Ibtidaiyyah & \\
\hline 12 & Tuntunan Pelajaaran I'rob & KH. Yahya Arif & I'rob & Ibtidaiyyah & \\
\hline 13 & $\begin{array}{l}\text { Al Kifayah Ala Tarjamatil } \\
\text { Ajrumiyyah }\end{array}$ & KH. Yahya Arif & Nahwu & Ibtidaiyyah & Juz $1-2$ \\
\hline 14 & Nahwu Jawan & KH. Yahya Arif & Nahwu & Ibtidaiyyah & \\
\hline 15 & $\begin{array}{l}\text { Al kafiyah fi Tarjamati } \\
\text { Khoridatul Bahiyyah }\end{array}$ & KH. Yahya Arif & Tauhid & Ibtidaiyyah & \\
\hline 16 & $\begin{array}{l}\text { 'athiyyatul Wadud fi } \\
\text { Tarjamati Nadhomul } \\
\text { IbtidaiyyahMaqshud }\end{array}$ & KH. Yahya Arif & Shorof & Ibtidaiyyah & \\
\hline 17 & Risalah Qawaa'idul I'lal & KH. Yahya Arif & I'lal & Ibtidaiyyah & \\
\hline 18 & Nujumun Nayyirat & KH. Yahya Arif & Zej & Tsanawiyyah & \\
\hline 19 & Risalah Tashilul A'mal & KH. Yahya Arif & Zej & Tsanawiyyah & \\
\hline 20 & $\begin{array}{l}\text { Tarjamah } \quad \text { Addurusul } \\
\text { Faraidliyyah }\end{array}$ & KH. Yahya Arif & Faraid & Tsanawiyyah & Juz 1-3 \\
\hline
\end{tabular}




\begin{tabular}{|c|c|c|c|c|}
\hline 21 & $\begin{array}{l}\text { Tarjamah } \\
\text { Falakiyyah }\end{array}$ & KH. Yahya Arif & Falak & Tsanawiyyah \\
\hline 22 & $\begin{array}{l}\text { Tarjamah } \\
\text { Maknun }\end{array}$ & H. Ashfal Maula & $\begin{array}{c}\text { Ma'ani, } \\
\text { Badi', Bayan }\end{array}$ & Tsanawiyyah \\
\hline 23 & $\begin{array}{l}\text { Tarjamah } \\
\text { Thuruqat }\end{array}$ & $\begin{array}{l}\text { KH M. Sya'roni } \\
\text { Ahmadi }\end{array}$ & Ushul Fiqih & Tsanawiyyah \\
\hline 24 & $\begin{array}{l}\text { Tarjamah Alfiyah Ibnu } \\
\text { Malik }\end{array}$ & H. Ashfal Maula & Nahwu & $\begin{array}{l}\text { Tsanawiyyah - Juz 1-7 } \\
\text { Aliyah }\end{array}$ \\
\hline 25 & $\begin{array}{l}\text { Tarjamah } \\
\text { Munauraq }\end{array}$ & $\begin{array}{l}\text { KH. M. Sya'roni } \\
\text { Ahmadi }\end{array}$ & Manthiq & Aliyah \\
\hline 26 & $\begin{array}{l}\text { Tarjamah Addurusul } \\
\text { Falakiyyah Juz } 3\end{array}$ & KH. Yahya Arif & Falak & Aliyah \\
\hline
\end{tabular}

These books aimed to make students easier to learn Kitab Kuning. The majority of the books were written in Javanese to make the students easy to understand. In addition, Javanese is the local Indonesian language so it also carries the Islam Nusantara mission. Beside that, the teaching material, which was no less archipelagic, is the astronomy book used at Madrasah Qudsiyyah, which taught the calculation of the aboge and asapon calendars as a form of Javanese identity, making students easier to understand the knowledge in Arabic. Most books written by these masyayikh were excerpts, summaries or even translations of classical Arabic books by middle eastern scholars. These masyayikhs tried to take their values or essence, then compiled them in language of mother tongue, Javanese, to preserve Islam Nusantara syiar's culture and mission.

\section{c. Learning Methods}

In the learning process, especially material using kitab kuning, the teachers employed the bandongan method, namely by interpreting kitab kuning editorial in Arabic using Javanese. Not only that, even in every linguistic structure in the editorial, such as tarkib, mubtada' was interpreted in Javanese as utawi, Khobar was interpreted as iku, tarkib fa'il was interpreted as sopo, maful was interpreted as ing, and so on. It is a typical Javanese style or model of translating. The students would easily remember the sentence structure and understand its meaning because it was interpreted in Javanese. With such a method, the teachers also indirectly transferred the Nusantara Islam values, the composition of the Arabic-style structure, namely nahwu in Arabic into nahwu in the Nusantara style. 
Apart from the methods mentioned above, the teachers also added the story method in specific materials. For example, the teacher inserted stories about traditions in the historical material, such as mitoni, weton, medun lemah, and others. KH. M Sya'roni provided understanding to the students related to the material in the faraidus saniyyah book, which is a collection of the Ahlus Sunnah wal Jama'ah (aswaja) arguments, also always exemplified the typical Nusantara traditions. When he came to the material about assodaqotu lil mayyit, he told the 3, 7, 40,100, 1000-day commemorations wrapped with tahlil yasin and alms or berkatan. By using that way, the students could understand that the concepts in aswaja and other materials were a form of affirming Nusantara traditions. KH Sya'roi also tried to find a religious basis related to Nusantara culture or traditions so that the students became aware that the traditions that had been taking place in the community were no longer in conflict with religion.

\section{d. Activity Essence}

Some activities that could stimulate the students' souls in exploring Islam Nusantara values, among others, were implanting the character of love for the homeland or national values. Islam Nusantara teaches the people to love the homeland. In Madrasah Qudsiyyah, the actualization of the Islam Nusantara values was also carried out through education of national values, reflected in curricular activities, such as the subjects of Pancasila and Citizenship (PKn), History, State Administration, and others. These various efforts to strengthen the national ethos were inherent in the national education system, both in the curriculum and the hidden curriculum. These various reinforcements were also found in intra-curricular and extracurricular activities. Extra-curricular activities that could foster national values included scouts to shape the students' virtuous characters, instill a sense of love for the homeland, have a family attitude, and always apply Pancasila, Dasadarma, and Trisatya values. Also, non-curricular activities were such as flag ceremonies. The raising of the red and white flag reflects the many noble values that can be grown. In addition, another thing that was no less essential in growing national character was chanting Shalawat Asnawiyah, which has been sovereign as one of the national prayers. Shalawat Asnawiyah was very popular among Madrasah Qudsiyyah students. This poem was created by KHR Asnawi, who was also the founder of Madrasah Qudsiyyah. This poem was always sung every day before teaching and learning activities began. In this poem, there was a spirit of national values, such as the lyrics that read aman aman aman aman Indonesia raya aman, which is a prayer for the Indonesian nation's security and glory. This love is for the homeland. In the end, it could become positive energy for the students. The national poetry also taught them to love their homeland. In addition to making them open to cultural 
values, the students grew into more sensitive individuals to everything happening around them. With songs, they did not think rigidly but were more flexible in finding solutions to various cases or problems they faced daily and became strong and confident individuals. It impacted students' ability to adapt to different environments or cultures and could better understand diversity.

Another activity is ziarah (pilgrimage), a nahdhiyyah tradition routinely carried out at this madrasah, both to the tomb of Sunan Kudus in the month of Muharram and to the tomb of the madrasah founder, KHR Asnawi, and other masyayikhs. This activity was intended to honor and pray for the muassis's services and in the context of preserving Nusantara traditions of sowan ancestors as a form of respect and receiving blessings from the elders. In addition, it was also a connector for the spirit of struggle and learning between generations.

In addition to routine madrasah activities as above, there were also activities in specific events, such as the Nusantara Ulama Book Exhibition, which exhibited 200 books written by ulama from various regions in Nusantara, exhibited at MA Qudsiyyah in a series of events to commemorate the Qudsiyyah century. From the books exhibited by the organizers, there were several legendary books from various generations of Nusantara scholars, such as the works of Shaykh Yasin al-Fadani, Shaykh Nawawi al-Bantani, Shaykh Mahfudh at-Tarmasi, KH Soleh Darat, KH Sahal Mahfudh, KH Maimoen Zubair, and other works. Among the hundreds of books, dozens were manuscripts or unprinted books, which were around 100 years old. The book was written by the author himself, KH Dahlan bin Abdullah. With this exhibition, hundreds of years old books from original Indonesian scholars have been preserved. Moreover, the values in the book could be learned and practiced by the current generation. In addition, from this exhibition of the Nusantara ulama books, it is possible to read the current state of affairs with the eyes of the ancient Nusantara scholars and compare the current era with the era of the previous scholars from these books.

There was also the Festival of the Quran and the Islam Nusantara treasures. This activity was carried out on the alumni initiative and in collaboration with Bayt Al Quran \& Istiqlal Museum (BQMI), Lajnah Pentashihan Mushaf Al Quran (LPMQ), Research and Development Agency and Training of the Ministry of Religion of the Republic of Indonesia. It lasted for one week, centered on the Qudsiyyah field, Jl. Kudus Asnavi. It exhibited the collections of Bayt Koran Museum Istiqlal Mosque (Jakarta), Research and Development Library of the Indonesian Ministry of Religion, and Semarang Religious Research and Development Center Library. In addition, various collections of Islam Nusantara treasures in the form of books and calligraphy from the Madrasah Qudsiyyah alumni were also exhibited. 
Seminars and halaqah were also held to support the event, including the Gusjigang Assembly Halaqah and the National Seminar on Indonesian Standard Mushaf. The activity was featured various Al Quran manuscripts and books were published by the Literature and Secretariat of the Ministry of Religion. The students could see and read the material or books displayed and ask questions directly to the exhibition booth staff. This exhibition was also part of introducing the Indonesian Standard Mushaf so that the public could know more deeply. In addition, it was also to reduce the perception circulating in the community that other than the Medina Mushaf is wrong, and even not the Ottomans should not be used. Thus, the exhibition on the development of the Al Quran Mushaf from time to time and the variety of Al Quran Mushaf in this world could be a medium for students and the community around Kudus Regency, in general to add insight into the Quran. Besides, many other activities, such as cultural santri concerts and independent santri halaqah, were held by the Qudsiyyah theater regarding Babad Kudus and traditional music.

\section{e. Teacher Productivity}

The scientific specifications possessed by the teachers certainly provided a distinctive color and nuance in this madrasah. The majority of teachers mastered the science of wisdom and became a reference for the surrounding community. The teachers usually shared their experiences in overcoming various societal problems, solved by Javanese science, acculturation of wisdom combined with Javanese tradition, for example, the concept of alms in eliminating logs. Teachers who became elders in their respective areas usually recommended making redwhite porridge a symbol of rejecting logs, which was then given or donated to neighbors. It was an example that the teacher's experience conveyed to the students in lessons certainly provided insight into the students about Javanese traditions, which are still being carried out until now.

\section{Conclusion}

The instilling of Islam Nusantara values in students' personalities through various ways and activities, as implemented in Madrasah Qudsiyah, started from the typical Kudusan uniform, reference materials in the form of Javanese books, learning methods to special event performances related to Islam Nusantara treasures, such as Quran Nusantara exhibition and Quran Nusantara festival. It is a solution to strengthen Indonesian. Beside that, the continuity of local culture with learning elements makes Islam Nusantara a discourse and spirit instilled in students. It is a necessity to strengthen Indonesian. By doing it, the Islam mission as rahmatan lil alamin is embodied in Islam Nusantara model. 


\section{REFERENCES}

Abdullah. 2016. "Pendidikan Agama dalam Bingkai Islam Di Nusantara." AL-ISHLAH Jurna 1 Studi Pendidikan 14 (1): 65.

Al-Zastrouw, Ngatawi. 2017. "Mengenal Sepintas Islam Nusantara, , Vol. 1, No.1, Januari 2017.” Hayula: Indonesian Journal of Multidisciplinary Islamic Studies 1 (1): 4.

Astuti, Hanum Jazimah Puji. 2017. "Islam Nusantara: Sebuah Argumentasi Beragama dalam Bingkai Kultur.” INJECT: Interdisciplinary Journal of Communication 2 (1): 50.

Azisi, Ali Mursyid. 2020.Islam Nusantara: Corak Keislaman Indonesia Dan Perannya Dalam Menghadapi Kelompok Puritan.EMPIRISMA: Jurnal Pemikiran dan Kebudayaan Islam Vol. 29 No. 2 Juli.

Azra, Azyumardi. 2004. Jaringan Ulama Timur Tengah dan Kepulauan Nusantara Abad XVII \& XVIII: Akar Pembaruan Islam Indonesia. Jakarta: Kencana.

Guba, E. G. \& Lincoln, Y. S. 1985. Naturalistic Inquiry. California: Sage Publications Inc.

Habib Shulton Asnawi dan Eka Prasetiawati. 2017. "Pribumisasi Islam Nusantara dan Relevansinya dengan Nilai-Nilai Kearifan Lokal di Indonesia, , Vol. 3, No. 1, Juni 2018.” Fikri 3 (1): 254.

Lubis, Ahmad Hafidz. 2018. "Islam Indonesia, Islam Nusantara,Islam Berkemajuan." Akademika $12(1): 75$.

Luthfi, Khabibi Muhammad. 2016. “Islam Nusantara: Relasi Islam dan Budaya Lokal." Shahih $1(1): 3$.

Muhadjir, Noeng. 2002. Metodologi Penelitian Kualitatif. Yogyakarta: Andi Ofset.

Qomar, Mujamil. 2015. "Islam Nusantara: Sebuah Alternatif Model Pemikiran, Pemahaman, dan Pengamalan Islam.” el Harakah 17 (2): 213-14.

Rahmat, M. Imdadun. 2007. Islam Pribumi : Mendialogkan Agama Membaca Realitas. Jakarta: Erlangga.

Ramdhoni, Faisol. 2016. "islam-nusantara-dan-islam-sehari-hari-potret-respon-dantantangangagasan-islam-nusantara-di-desa,.” nu.or.id. 2016.

www.nu.or.id/post/read/61002/islam-nusantara-dan-islam-sehari-hari-potret-respondantantangan-\%0Agagasan-islam-nusantara-di-desa,. 
